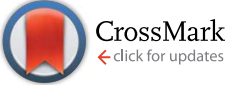

Cite this: RSC Adv., 2017, 7, 11297

\title{
Homogeneous capture and heterogeneous separation of proteins by PEG-functionalized ionic liquid-water systems
}

\author{
Wenhui Yao, ${ }^{\text {ab }}$ Huiyong Wang, ${ }^{a}$ Yuanchao Pei, ${ }^{a}$ Yuehua Chen, ${ }^{a}$ Zhiyong Li ${ }^{a}$ \\ and Jianji Wang*a
}

Extraction and separation of proteins is important for their interesting applications as continuous enzymatic reaction and/or product separation systems. In this work, a new highly efficient homogeneous capture and heterogeneous liquid-liquid separation strategy is presented for the extraction of proteins from aqueous solution by PEG (poly(ethylene glycol))-functionalized ionic liquids, which have a lower critical solution temperature (LCST) phase behaviour in water. The factors influencing the solvent extraction process such as homogeneous capture time, $\mathrm{pH}$ value of aqueous phase and water content in the ionic liquids were investigated systematically. It was found that homogeneous capture of the proteins was quite fast, typically 1 min was enough to achieve equilibrium, and the extraction efficiency was greatly affected by water phase $\mathrm{pH}$ value and water content in the ionic liquid phases. Under optimal conditions, the singlestep extraction efficiency by $\left[\mathrm{PEG}_{800}(\mathrm{mim})_{2}\right]\left[\mathrm{NTf}_{2}\right]_{2}$ was higher than $95 \%$ for most of the studied proteins (cytochrome c, myoglobin, hemoglobin, lysozyme and papain), but it was only $8 \%$ for bovine serum and $2 \%$ for peroxidase. Based on the significant differences in the extraction efficiencies observed, selective separation of the proteins from bovine serum or/and peroxidase was successfully performed using the IL/water mixture. In addition, circular dichroism and FT-IR spectroscopy were used to probe the structure and conformation change of the proteins, and the extraction mechanism was also discussed from the point of view of the electrostatic and hydrophobic/hydrophilic interactions of proteins with ionic liquids.

Received 20th December 2016 Accepted 9th February 2017

DOI: $10.1039 / c 6 r a 28483 c$

rsc.li/rsc-advances
Some ILs having hydrophobic anions/cations can easily form liquid-liquid biphase systems after mixing with water, which makes them interesting alternatives for conventional organic solvents used in liquid-liquid extraction. ${ }^{12-15}$ However, very few reports can be found in the literature on the direct extraction of proteins from water using hydrophobic ILs $^{\mathbf{1 6}}$ due to the limited solubility and possible denaturation of proteins in most of neat hydrophobic ILs. Later, some ILs systems with the addition of an extractant have been developed to extract proteins or enzymes from water. ${ }^{\mathbf{1 7}}$ In this procedure, sonication or much time shaken is usually applied in spite of fear of protein decomposition. Recently, extraordinary stability of proteins in ILs with a certain amount of water has been reported by a few groups, ${ }^{18-20}$ which cannot be realized in neat water. Thus, there are a growing number of publications on aqueous two phase systems (ATPSs) based on ILs for the primary recovery and purification of a variety of biological products. ${ }^{21-23}$ However, high concentrations of inorganic salts are always used in the ILbased ATPSs. This will produce a great amount of highly salty water in the application, thus causing environmental problems. Therefore, the development of highly efficient and environmentally friendly methods for the protein extraction is still a challenge.

\footnotetext{
${ }^{a}$ Collaborative Innovation Center of Henan Province for Green Manufacturing of Fine Chemicals, School of Chemistry and Chemical Engineering, Key Laboratory of Green Chemical Media and Reactions, Ministry of Education, Henan Normal University, Xinxiang, Henan 453007, P. R. China.E-mail: jwang@htu.cn

${ }^{b}$ School of Civil Engineering, Xinxiang University, Xinxiang, Henan 453003, P. R. China
}

\section{a challenge.}


In principle, if one strategy can be used to realize the homogeneous capture and heterogeneous liquid-liquid separation of proteins, the extraction efficient would be enhanced and the consumed energy could be decreased. Actually, some ILs have been found to possess upper critical solution temperature (UCST)-type phase transition or lower critical solution temperature (LCST)-type phase transition in $\mathrm{H}_{2} \mathrm{O} \cdot{ }^{24-26}$ It is expected that these aqueous ILs systems can be applied in homogeneous capture and heterogeneous separation of proteins. Indeed, Binnemans et al. ${ }^{27}$ found that betainium bis(trifluoromethylsulfonyl)imide-water mixture with an UCST phase behavior could be used for homogeneous capture and heterogeneous separation of metal ions. This provides an energy-saving extraction strategy due to the fast mass transfer speed and kinetic, and the shorter extraction equilibrium time. Other examples were also reported for the extraction of metal ions with such a strategy. ${ }^{28-30}$ However, to our knowledge, only one report can be found in the literature on the extraction of biopolymers such as proteins with this new strategy ${ }^{31}$ primarily due to the fact that proteins are often sensitivity to temperature, and high temperature can cause protein denaturation. On the other hand, in the thermo-responsive ILs/water mixture, the amount of water in the IL phase is strongly dependent on the temperature, which is also important for the stability and extraction efficiency of protein. Therefore, design of ILs with convenient phase separation temperature range in water is the key to achieve highly effective and safe extraction and separation of proteins from water.

Poly(ethylene glycol) (PEG) is important in many industrial, environmental, and biological applications because of its unique properties, such as non-toxicity, non-volatility, and biocompatibility. ${ }^{32}$ Incorporating PEG moiety into cationic (or anionic) unit of ILs can yield PEG-functionalized ILs. These ILs are a new appealing group of liquid materials and have found various applications in chemical synthesis, ${ }^{33}$ biomass dissolution, ${ }^{34}$ stabilization of proteins ${ }^{35}$ and nanoparticles. ${ }^{36}$ In a recent work, ${ }^{37}$ we have designed, synthesized and characterized a new class of PEG-functionalized imidazolium ILs $\left[\mathrm{PEG}_{m}(\mathrm{mim})_{2}\right]\left[\mathrm{NTf}_{2}\right]_{2}$ (with PEG average molecular weight $m=200,400,600,800$ and 1000), and their chemical structures were shown in Chart 1 . It was found that these ILs exhibited unique LCST phase behavior in water. ${ }^{38}$ The phase separation temperature was lower than $50{ }^{\circ} \mathrm{C}$ and could be tuned by the molecular weight of PEG middle block at any composition of the mixtures due to the fact that hydrophilicity of the ILs increases with increasing molecular weight of the PEG middle block. For example, when $\left[\mathrm{PEG}_{800}(\mathrm{mim})_{2}\right]\left[\mathrm{NTf}_{2}\right]_{2}$ was mixed with an equal amount of water (50 wt\%), the LCST-type

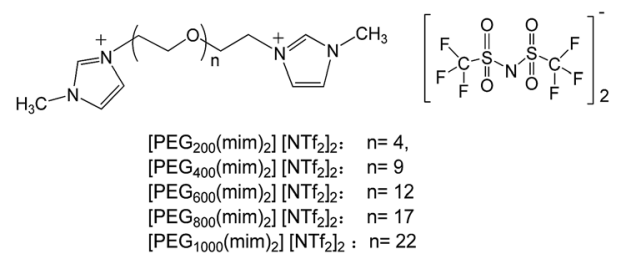

Chart 1 Chemical structures of the ILs investigated in this work. phase separation temperature could be observed at $25{ }^{\circ} \mathrm{C}$. This should be an ideal system for homogeneous capture (say at $22^{\circ} \mathrm{C}$ ) and heterogeneous separation (say at $27^{\circ} \mathrm{C}$ ) of proteins. In this work, we show the possibility to use these ILs for the homogeneous capture and heterogeneous separation of some proteins from water.

\section{Experimental section}

\section{Materials}

All the $\left[\mathrm{PEG}_{m}(\mathrm{mim})_{2}\right]\left[\mathrm{NTf}_{2}\right]_{2}$ ILs were synthesized, purified, and characterized according to the procedures described previously. ${ }^{37}$ The purities of these ILs were found to be higher than $99.0 \mathrm{wt} \%$, as determined by quantitative ${ }^{1} \mathrm{H}$ NMR measurements. ${ }^{38}$ Myoglobin ( $\mathrm{Mb}$ ) from horse heart, hemoglobin ( $\mathrm{Hb}$ ) from bovine blood, albumin from bovine serum (BSA), trypsin from bovine pancreas, horseradish peroxidase (HRP) and lysozyme (Lyz) from chicken egg white, cytochrome c (Cyt.c) and papain were purchased from Sigma-Aldrich. All the proteins were used as received without further purification. Doubly distilled deionized water was used throughout the experiments. $1.0 \mathrm{M}$ aqueous $\mathrm{HCl}$ or $\mathrm{NaOH}$ was used to adjust the $\mathrm{pH}$ of the systems.

\section{Homogeneous capture and heterogeneous liquid-liquid separation of the proteins}

In the extraction experiments, an IL such as $\left[\mathrm{PEG}_{800}(\mathrm{mim})_{2}\right]$ $\left[\mathrm{NTf}_{2}\right]_{2}$ was presaturated with water to minimize phase volume change when mixed with water. At the moment, the IL is classified as "hydrated IL". Then, $1.0 \mathrm{ml}$ of the presaturated IL was mixed with $1.0 \mathrm{ml}$ of aqueous protein solution $\left(1.0 \mathrm{mg} \mathrm{ml}^{-1}\right)$ at room temperature. The resulting IL/water solution was changed into a single phase instantly under stirring and cooling in a water bath at $22.0{ }^{\circ} \mathrm{C}$. After $1 \mathrm{~min}$, this homogeneous solution was heated to $27.0^{\circ} \mathrm{C}$ and left to stand until the separated water phase became clear. At this temperature, a $29.5 \mathrm{wt} \%$ of water content was determined gravimetrically ${ }^{39}$ for the IL phase. Once the volume of the top and bottom phases was recorded, concentrations of the protein in aqueous phases were measured by using a UV spectrophotometer (BeijingTU-1900), and the protein concentrations in IL phase was calculated by mass balance. The maximum absorption band at $408 \mathrm{~nm}$ was used to determine concentrations of the heme proteins Cyt.c, Mb, HRP and $\mathrm{Hb}$, while the absorbance at $280 \mathrm{~nm}$ was used for the concentration determination of the other proteins. The relative error in the proteins concentration measurements was estimated to be within $5 \%$. To avoid the interference from the phase components, the samples were diluted and analyzed against the blanks containing the same phase components but without protein. Partition coefficients $(K)$ and extraction efficiencies $(E \%)$ of the proteins were calculated by using the equations:

$$
\begin{gathered}
K=\frac{C_{\mathrm{i}}-C_{\mathrm{f}}}{C_{\mathrm{i}}} \times \frac{V_{\mathrm{aq}}}{V_{\mathrm{IL}}} \\
E(\%)=\frac{C_{\mathrm{i}}-C_{\mathrm{f}}}{C_{\mathrm{i}}} \times 100 \%
\end{gathered}
$$


where $C_{\mathrm{i}}$ and $C_{\mathrm{f}}$ are the protein concentrations in the aqueous phase before and after extraction, $V_{\mathrm{aq}}$ and $V_{\mathrm{IL}}$ are the volumes of the aqueous phase and IL phase, respectively.

\section{Circular dichroism and FT-IR spectroscopic measurements}

Circular dichroism (CD) spectra (300-500 nm) of Cyt.c in water and in the IL phase after extraction were determined at room temperature by using a Jasco J-820 CD spectropolarimeter, where [Cyt.c] $=1.0 \mathrm{mg} \mathrm{ml}^{-1}$ and the optical path length is 1 mm. IR spectra for Cyt.c in $\mathrm{D}_{2} \mathrm{O}$ and $\mathrm{D}_{2} \mathrm{O}$-saturated IL phase were recorded on a PerkinElmer FT-IR spectrometer at room temperature with 16 scans at $4 \mathrm{~cm}^{-1}$ resolution for an acceptable signal-to-noise ratio.

\section{Results and discussion}

\section{Extraction of Cyt.c from water to the IL phases}

Here, Cyt.c was used as a representative protein to investigate the liquid-liquid extraction process since it is one of the most thoroughly characterized metalloproteins. ${ }^{\mathbf{4 0 , 4 1}}$ The course to use $\left[\mathrm{PEG}_{800}(\mathrm{mim})_{2}\right]\left[\mathrm{NTf}_{2}\right]_{2}$ for the homogeneous capture and heterogeneous liquid-liquid separation of Cyt.c was shown in Fig. 1. First, $1.0 \mathrm{ml}$ of aqueous Cyt.c solution $\left(1.0 \mathrm{mg} \mathrm{ml}^{-1}\right)$ was added to $1.0 \mathrm{ml}$ of the presaturated IL at room temperature. At this temperature, the aqueous phase was formed on the top of the IL phase (Fig. 1a), and Cyt.c was mainly present in the aqueous phase. Once the system was cooled to $22.0^{\circ} \mathrm{C}$, the two separated phases immediately became a homogeneous solution under stirring (Fig. 1b). After staying for $1 \mathrm{~min}$, phase separation was then induced by gentle heating to $27^{\circ} \mathrm{C}$ and then left it to stand until the colorless top phase was formed (Fig. 1c). In this way, the protein was exclusively exacted in the IL phase (bottom).

To investigate the influence of homogeneous capture time on the extraction efficiency, each solution containing $1.0 \mathrm{ml}$ of proteins and $1.0 \mathrm{ml}$ of water-saturated $\left[\mathrm{PEG}_{800}(\mathrm{mim})_{2}\right]\left[\mathrm{NTf}_{2}\right]_{2}$ was performed with the same procedure except for the different homogeneous capture time. Fig. 2 shows the extraction efficiency of Cyt.c as a function of homogeneous capture time. It can be seen that the extraction efficiency of the protein could reach to $98.1 \%$ in 5 seconds. After 1 minute, no significant

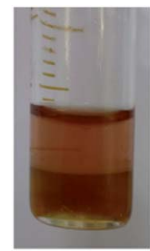

(a)

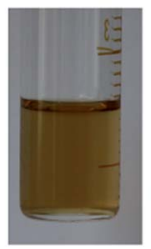

(b)

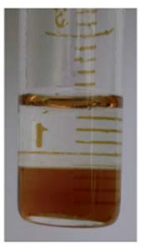

(c)
Fig. 1 Homogeneous capture and heterogeneous liquid-liquid separation of Cyt.c (1.0 mg ml $\mathrm{m}^{-1}$ ) by changing the temperature: (a), an aqueous solution of Cyt.c was added to $\left[\mathrm{PEG}_{800}(\mathrm{mim})_{2}\right]\left[\mathrm{NTf}_{2}\right]_{2}$ at room temperature; (b), homogeneous capture of the protein for $1 \mathrm{~min}$ at $22{ }^{\circ} \mathrm{C}$; (c), heterogeneous liquid-liquid separation of Cyt.C at $27^{\circ} \mathrm{C}$. The upper layer is aqueous phase and the lower layer is the IL phase.

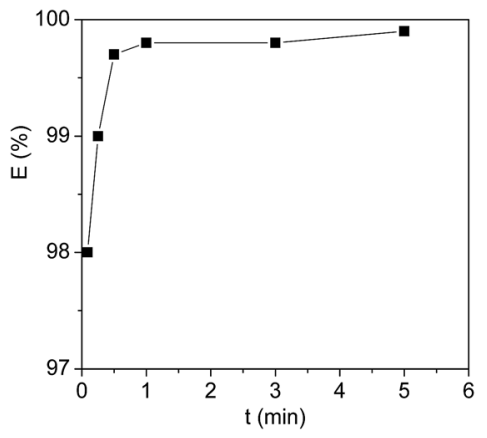

Fig. 2 Extraction efficiency of Cyt.c by $\left[\mathrm{PEG} \mathrm{Goo}_{80}(\mathrm{mim})_{2}\right]\left[\mathrm{NTf}_{2}\right]_{2}$ at $27^{\circ} \mathrm{C}$ as a function of homogeneous capture time. The protein concentration $=1 \mathrm{mg} \mathrm{ml}^{-1}, \mathrm{pH}=7.0$.

changes in the extraction efficiency (99.8\%) could be observed. Compared with the conventional liquid-liquid extraction systems, this very short equilibrium time is understandable since mass transfer and kinetics was significantly accelerated due to the molecular level mixing at the temperature below LCST. Therefore, $1 \mathrm{~min}$ was chosen to insure the attainment of extraction equilibrium.

\section{Effect of water content in the ILs phases on proteins extraction}

In the thermo-responsive ILs/water two phase mixtures investigated in this work, the amount of water in the ILs phases is strongly dependent on both the temperature and the molecular weight of PEG chains of the ILs. In order to realize the protein extraction at room temperature, water content in the IL phase can be controlled by tuning the molecular weight of PEG chains of the ILs. Because the phase separation temperature $\left(45^{\circ} \mathrm{C}\right)$ of $\left[\mathrm{PEG}_{1000}(\mathrm{mim})_{2}\right]\left[\mathrm{NTf}_{2}\right]_{2}$ in equal weight of water was not convenient for the extraction, $\left[\mathrm{PEG}_{200}(\mathrm{mim})_{2}\right]\left[\mathrm{NTf}_{2}\right]_{2},\left[\mathrm{PEG}_{400}{ }^{-}\right.$ $\left.(\mathrm{mim})_{2}\right]\left[\mathrm{NTf}_{2}\right], \quad\left[\mathrm{PEG}_{600}(\mathrm{mim})_{2}\right]\left[\mathrm{NTf}_{2}\right]_{2}$ and $\left[\mathrm{PEG}_{800}(\mathrm{mim})_{2}\right]$ $\left[\mathrm{NTf}_{2}\right]_{2}$ were performed with the same procedure to study the effect of water content in the ILs phases on protein extraction. Fig. 3 shows the extraction efficiency of Cyt.c at $27.0{ }^{\circ} \mathrm{C}$ as a function of water content of the ILs phases. It can be seen

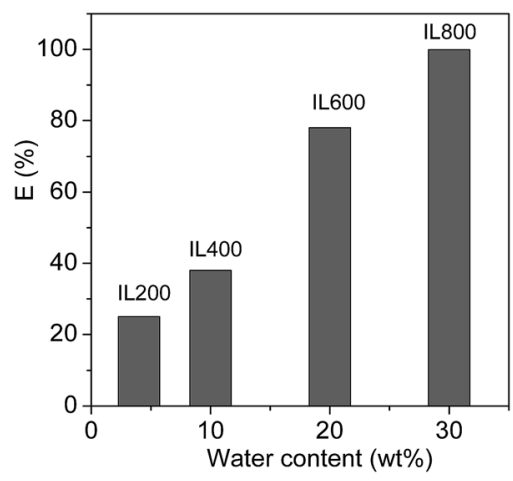

Fig. 3 The extraction efficiency of Cyt.c at $27^{\circ} \mathrm{C}$ as a function of water content in the ILs phases of $\left[P \mathrm{PE}_{200}(\mathrm{mim})_{2}\right]\left[\mathrm{NTf}_{2}\right]_{2},\left[\mathrm{PEG}_{400}(\mathrm{mim})_{2}\right]$ $\left[\mathrm{NTf}_{2}\right]_{2},\left[\mathrm{PEG} \mathrm{G}_{600}(\mathrm{mim})_{2}\right]\left[\mathrm{NTf}_{2}\right]_{2}$ and $\left[\mathrm{PEG} \mathrm{G}_{800}(\mathrm{mim})_{2}\right]\left[\mathrm{NTf}_{2}\right]_{2}$. 
from Fig. 3 that the extraction efficiency increased with increasing water content in the ILs phase. These results indicate that the extraction of proteins was closely related to water content in the ILs phases. Fujita et al. ${ }^{18}$ reported that mixtures of small amount of water and hydrophilic ILs with oxo acid residues were effective in dissolving proteins. They suggested that the small amount of water present in the ILs was probably involved in direct interaction with the proteins. In fact, the transfer of protein to the IL phase requires the breaking of the interaction between the cation and anion to create a cavity where the protein will be included, and the energy for this process would be obtained from the interactions between proteins and the IL. Because of the presence of water, the association between cation and anion of the IL is partially disrupted, leading to an increase both in the number of free ions and in the ionic mobility of the IL, which may enhance the interactions of the IL with protein. In addition, it has been reported that PEG is an effective chemical modifier for improving the solubility of Cyt.c in solvents including ILs without denaturation. ${ }^{42}$ These results clearly demonstrate that the partitioning of a protein into the PEG functionalized ILs is controllable on the basis of tuning molecular weight of PEG chains and water content in the ILs phases. A suitable amount of water is necessary to efficiently extract Cyt.c, and the hydrated state of ions may play an important role in controlling the affinity with proteins.

\section{Effect of $\mathrm{pH}$ on the extraction efficiency of the proteins}

The extraction efficiency is expected to depend on the surface net charge of the proteins which can be adjusted by the $\mathrm{pH}$ values of the systems. To confirm the effect of the $\mathrm{pH}$ values, the extraction efficiency of Cyt.c was studied, as an example, as a function of $\mathrm{pH}$, and the results were shown in Fig. 4. In this study, $\mathrm{pH}$ range of $2.3-12.5$ was chosen to examine the $\mathrm{pH}$ dependence of proteins extraction because protein can easily be denatured at extreme $\mathrm{pH}$ values. It can be seen from Fig. 4 that the extraction efficiency of Cyt.c was kept constant at about $99.8 \%$ within the range of $\mathrm{pH}<10$, but sharply decreased when the $\mathrm{pH}$ value was over the isoelectric point (10.2) of the protein.

It is known that isoelectric point (pI) value of horse heart Cyt.c is 10.2, which indicates that Cyt.c exists as a cationic $\left(-\mathrm{NH}_{3}{ }^{+}\right)$species under neutral or acid conditions, while Cyt.c

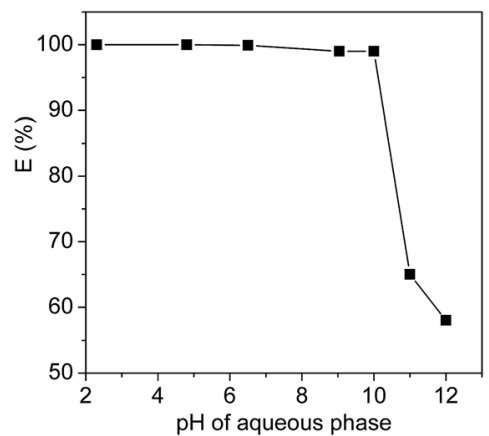

Fig. 4 Extraction efficiencies of Cyt.c by $\left[\mathrm{PEG}_{800}(\mathrm{mim})_{2}\right]\left[\mathrm{NTf}_{2}\right]_{2}$ as a function of the $\mathrm{pH}$ of the systems at $27^{\circ} \mathrm{C}$. exists as a anion $\left(-\mathrm{COO}^{-}\right)$species when the $\mathrm{pH}$ values was over the isoelectric point value. This clearly indicates that surface charged groups in the protein is an important factor for the extraction efficiency of Cyt.c by the IL. The $\left(\mathrm{CH}_{2} \mathrm{CH}_{2} \mathrm{O}\right)_{n}$ segments of PEG chains of the ILs are probably prefer to interact with the ammonium cation $\left(-\mathrm{NH}_{3}^{+}\right)$instead of anion $\left(-\mathrm{COO}^{-}\right)$of Cyt.c by favourable hydrogen bonding and ion-dipole interactions, which allows the transfer of protein into the IL phase. In addition, considering the fact that the PEG-functionalized ILs used in this study include dications and exhibit a distinctive electrical double layer at the electrode surface, ${ }^{\mathbf{4 3 4 4}}$ the stronger columbic interaction between the imidazolium cation and protein is another possible driving force for the extraction of Cyt.c.

\section{Extraction efficiency of the proteins in the ILs-water systems}

Based on the above discussion on the extraction of Cyt.c from aqueous solution, the partition behavior of the other proteins in $\left[\mathrm{PEG}_{800}(\mathrm{mim})_{2}\right]\left[\mathrm{NTf}_{2}\right]_{2}$-water systems was also investigated at $\mathrm{pH} 7$, and the results were given in Fig. 5, where the partition coefficients of these proteins varied from 0.05 to 53.0 (not shown). It is clearly indicated that by a single-step extraction procedure, $99.8 \%$ of Cyt.c, $\mathrm{Mb}$ and $\mathrm{Hb}, 99.0 \%$ of lysozyme, $95.0 \%$ of papain, and $88.9 \%$ of trypsin could be extracted into the IL phase. However, HRP and BSA were remained in the aqueous phase and the extraction efficiency was only $8 \%$ for BSA and $2 \%$ for HRP.

It is known that the proteins used in this study have different isoelectric points in water, which are 10.2 for Cyt.c, 7.0 for $\mathrm{Hb}$ and Mb, 7.2 for HRP, 8.7 for papain, 11.4 for Lyz, 9.4 for trypsin and 4.6 for BSA, respectively. Because the $\mathrm{pH}$ of $\mathrm{IL}-\mathrm{H}_{2} \mathrm{O}$ system was fixed at 7.0, the isoelectric points of $\mathrm{Hb}, \mathrm{Mb}$ and HRP are close to the $\mathrm{pH}$ value of $\mathrm{IL}-\mathrm{H}_{2} \mathrm{O}$ system and the net charges of these proteins are null. On the other hand, the net charges of proteins including Cyt.c, Lyz, papain and trypsin are positive, but that of BSA is negative under the experimental conditions. At this stage, it is not difficult to understand why Cyt.c, Lyz, papain and trypsin could be easily extracted by the IL, and why BSA could not be extracted into the IL. However, although $\mathrm{Hb}$, $\mathrm{Mb}$ and HRP have similar isoelectric point in value, the extraction efficiency of heme proteins of $\mathrm{Hb}$ and $\mathrm{Mb}$ was much

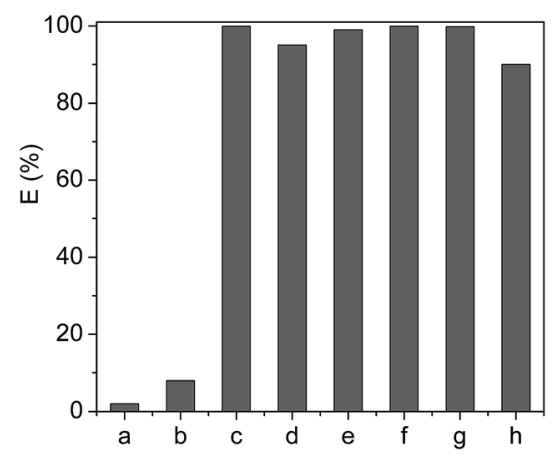

Fig. 5 Extraction efficiency of the proteins $\left(1 \mathrm{mg} \mathrm{ml}^{-1}\right)$ by $\left[\mathrm{PEG}_{800}\right.$ $\left.(\text { mim) })_{2}\right]\left[\mathrm{NTf}_{2}\right]_{2}$ at pH 7.0 (a), HRP; (b), BSA; (c), Cyt.c; (d), papain; (e), Lyz; (f), $\mathrm{Mb}$; (g), $\mathrm{Hb}$ and (h), typsin. 
higher than that of HRP. This result suggests that the extraction efficiency of the proteins cannot be explained only by their surface charge, there are other factors such as hydrophobicity/ hydrophilicity of proteins, which are also important for affecting the extraction efficiency. For example, hydrophilic glycoside chains present in HRP tend to remain this protein in the aqueous phase in spite of the belief that PEG chain can more easily wrap-up or coordinate with heme-group of the protein, ${ }^{45}$ leading to its low extraction efficiency.

\section{Selective separation of the target protein}

As mentioned in Fig. 5, extraction efficiency of the proteins in the $\left[\mathrm{PEG}_{800}(\mathrm{mim})_{2}\right]\left[\mathrm{NTf}_{2}\right]_{2}$-water system varies significantly. This suggests that HRP or BSA could be selectively separated from its mixture with Cyt.c, papain, Lyz, Mb, $\mathrm{Hb}$ and typsin. To confirm this deduction, $0.5 \mathrm{ml}$ of aqueous Cyt.c $\left(1.0 \mathrm{mg} \mathrm{ml}^{-1}\right)$ and $0.5 \mathrm{ml}$ of aqueous HRP $\left(1.0 \mathrm{mg} \mathrm{ml}^{-1}\right)$ were mixed to obtain a $1.0 \mathrm{ml}$ of aqueous solution of the proteins. Then, $1.0 \mathrm{ml}$ of the presaturated IL was added, and the mixture was cooled to $22.0{ }^{\circ} \mathrm{C}$ to generate a homogeneous solution. After capture of the protein, the solution was heated to $27.0^{\circ} \mathrm{C}$ to induce phase separation. The content of proteins isolated in each phase was analyzed by $15 \%$ of standard SDS-PAGE (sodium dodecyl sulfate-polyacrylamide gel electrophoresis), and the gel was stained with Coomassie Brilliant Blue R-250. It is clearly observed from Fig. 6 that both phases exhibited a single band, but in different positions. The lane for the IL phase (Fig. 6a) showed a band at $12.5 \mathrm{kDa}$, which was assigned to Cyt.c, whereas the lane for the water phase (Fig. 6b) showed a band at $44 \mathrm{kDa}$, which corresponded to HRP. This shows that both Cyt.c and HRP were fully separated in the $\mathrm{IL} /$ water mixture.

\section{Possible structure and conformation change of the proteins after extraction}

Fig. 7 shows the soret region CD spectra $(350-450 \mathrm{~nm})$ of native Cyt.c in water and in $\left[\mathrm{PEG}_{800}(\mathrm{mim})_{2}\right]\left[\mathrm{NTf}_{2}\right]_{2}$ phase. It can be seen that a negative peak at $417 \mathrm{~nm}$ and a positive peak at $404 \mathrm{~nm}$ appeared in water due to a split cotton effect for native Cyt.c in $\mathrm{H}_{2} \mathrm{O}$. The negative band was resulted from the

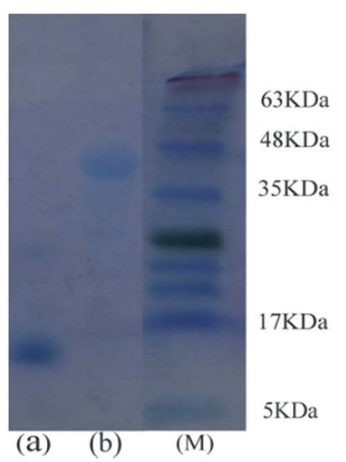

Fig. 6 The standard SDS-PAGE analysis. (a), The IL phase; (b), the aqueous phase after separation of Cyt.c and HRP; (M), shows molecular mass markers $(5-245 \mathrm{kDa})$. The band at $12.5 \mathrm{kDa}$ was assigned to Cyt.c and the band at $44 \mathrm{kDa}$ to HRP.

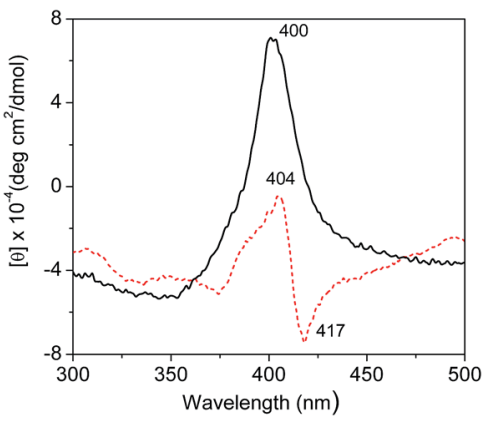

Fig. 7 CD spectra (300-500 nm) of Cyt.c (1.0 mg ml$^{-1}$ ) in water (red, broken line) and in $\left[\mathrm{PEG}_{800}(\mathrm{mim})_{2}\right]\left[\mathrm{NTf}_{2}\right]_{2}$ phase after extraction (black, solid line).

interaction of $\mathrm{Phe}^{80}$ (phenylalanyl-80) with heme on the $\mathrm{Met}^{80}$ (methionyl-80) side of the heme plane, and axial coordination of the low spin heme iron with $\mathrm{His}^{18}$ (histidyl-18) and $\mathrm{Met}^{80}$ strongly stabilized the native tertiary structure. ${ }^{46}$ In the $\left[\mathrm{PEG}_{800}(\mathrm{mim})_{2}\right]\left[\mathrm{NTf}_{2}\right]_{2}$ phase, the CD spectrum was characterized by the disappearance of the negative cotton effect and a concomitant increase in the intensity of the positive cotton effect at $400 \mathrm{~nm}$. These changes indicates that the cleavage of the sixth coordinating bond occurred between iron and the $\mathrm{Met}^{80}$, which probably resulted mainly from favorable interactions between Cyt.c and $\left(\mathrm{CH}_{2} \mathrm{CH}_{2} \mathrm{O}\right)_{n}$ segments of the PEG chain in the IL. The fact that ILs with shorter PEG chain such as $\left[\mathrm{PEG}_{200}(\mathrm{mim})_{2}\right]\left[\mathrm{NTf}_{2}\right]_{2}, \quad\left[\mathrm{PEG}_{400}(\mathrm{mim})_{2}\right]\left[\mathrm{NTf}_{2}\right]_{2}$ and $\left[\mathrm{PEG}_{600}\right.$ $\left.(\mathrm{mim})_{2}\right]\left[\mathrm{NTf}_{2}\right]_{2}$ had lower extraction efficiency for Cyt.c supports this speculation.

Similar phenomenon was also observed for Cyt.c from an aqueous phase into $\left[\mathrm{C}_{2} \mathrm{OHmim}\right]\left[\mathrm{NTf}_{2}\right]$ with crow ether complexation. ${ }^{47}$ These results suggest a change in heme-polypeptide interactions in the vicinity of the heme active site and an increase in the planarity of the ferric heme moiety, which can trigger the functional conversion of Cyt.c from an electrontransfer protein to peroxidase. ${ }^{46,48}$ Unfortunately, we could not take an accurate measurement of the CD spectrum in the $\alpha$ helix region (190-230 nm) of Cyt.c to examine the secondary structure of this protein, because of the interference of the IL in

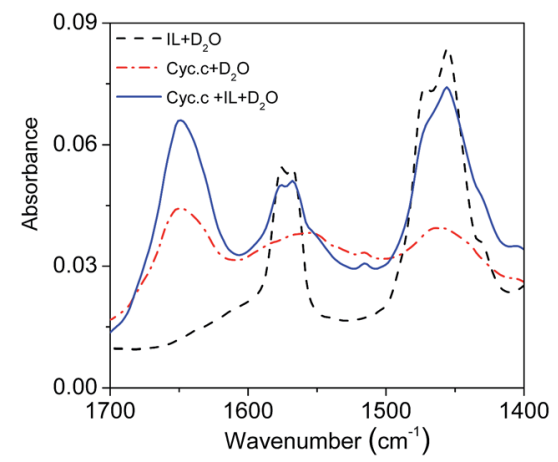

Fig. 8 FT-IR spectra of the $\left[\mathrm{PEG}_{800}(\mathrm{mim})_{2}\right]\left[\mathrm{NTf}_{2}\right]_{2}$ phase (black, solid line) as well as those of Cyt.c in $\mathrm{D}_{2} \mathrm{O}$ (red, dash dot line) and in the IL phase after extraction (blue, dash line). 
the range of short-wavelength light. Therefore, the findings from CD investigations only confirm that the change in tertiary structure of Cyt.c was mainly resulted from its interaction with PEG chain of the IL.

FT-IR spectroscopy is one of the classical experimental methods to provide information on secondary structure features of proteins. ${ }^{49,50}$ It is known that amide is a basic unit of the peptide bond: amide $\mathrm{I}$ is characterized by both $\mathrm{C}=\mathrm{O}$ stretching and ring stretching vibrations, while amide II is characterized only by $\mathrm{C}-\mathrm{N}$ stretching vibration. The absorption bands most widely used as structure probes in protein FT-IR spectroscopy is the amide I vibrations, which fall in the range of $1690-1600 \mathrm{~cm}^{-1} \cdot{ }^{49}$ FT-IR spectra of Cyt.c in $\left[\mathrm{PEG}_{800}(\mathrm{mim})_{2}\right]$ $\left[\mathrm{NTf}_{2}\right]_{2}$ phase after extraction were determined and compared with those of the protein in water to examine the influence of the IL on the secondary structure of Cyt.c. Fig. 8 shows FT-IR spectra of neat IL in $\mathrm{D}_{2} \mathrm{O}$, Cyt.c in $\mathrm{D}_{2} \mathrm{O}$, and Cyt.c in IL phase after extraction ( $\left(\mathrm{IL}-\mathrm{D}_{2} \mathrm{O}\right)$. Here, $\mathrm{D}_{2} \mathrm{O}$ was used instead of $\mathrm{H}_{2} \mathrm{O}$ as the solvent to eliminate the overlap of the $\mathrm{O}-\mathrm{H}$ stretching of $\mathrm{H}_{2} \mathrm{O}$ with amide I stretching of Cyt.c in the range of 1690-1600 $\mathrm{cm}^{-1}$. As can be seen from Fig. 8, amide I bond of the protein in the IL phase was identified to be the same with that in $\mathrm{D}_{2} \mathrm{O}$, suggesting no observable change of the secondary structure of Cyt.c in the IL phase. This is very important for keeping protein activity during the extraction. However, amide II bond of the protein could not be identified clearly because of the overlapped $\mathrm{C}-\mathrm{N}$ stretching of cation of the IL. Therefore, we can conclude that $\left[\mathrm{PEG}_{800}(\mathrm{mim})_{2}\right]\left[\mathrm{NTf}_{2}\right]_{2}$ provides a gentle environment for biomacromolecules.

\section{Conclusions}

In this work, a homogeneous capture and heterogeneous liquid-liquid separation strategy is reported for the extraction of proteins by PEG-functionalized ILs $\left[\mathrm{PEG}_{m}(\mathrm{mim})_{2}\right]\left[\mathrm{NTf}_{2}\right]_{2}-$ water systems. These ILs exhibited LCST phase behaviour in water, and the phase separation temperature and water content of the systems can be tuned for the efficient extraction of proteins by changing molecular weight of PEG chains of the ILs. It was found that the extraction efficiency of proteins was strongly dependent on the surface charges of the proteins and water content of the ILs phases. Under optimal conditions, by a single-step extraction procedure, $99.8 \%$ of $\mathrm{Cyt} . \mathrm{c}, \mathrm{Mb}$ and $\mathrm{Hb}$, $99.0 \%$ of lysozyme, $95.0 \%$ of papain, and $88.9 \%$ of trypsin could be extracted into the IL phase. However, HRP and BSA were remained in the aqueous phase and the extraction efficiency was only $8 \%$ for BSA and $2 \%$ for HRP. From the considerable difference in the extraction efficiency, selective extraction of proteins from HRP and/or BSA was realized by using the IL/ water mixture. $\mathrm{CD}$ and FT-IR spectra investigation suggest that only tertiary structure of Cyt.c in the IL phase changes after extraction, resulted from the interaction of the protein with PEG chain of the IL. But no native secondary structure change was observed for the protein. Therefore, the ILs-water systems provide a gentle environment for proteins.

Compared with the ILs based liquid-liquid extraction systems for proteins, the ILs-water systems developed in this work have many advantages such as very fast mass transfer and kinetics because of the molecular level mixing during the homogeneous capture of protein, tuneable phase separation temperature and water content of the ILs phases due to the functionalization of the ILs with different molecular weights of PEG chains. In addition, the preparation of the ILs is more simple and inexpensive. Therefore, these PEG-functionalized ILs mixed with water provide highly efficient, fast and environmentally friendly systems for the recovery and selective separation of proteins.

\section{Acknowledgements}

This work was supported by the National Natural Science Foundation of China (No. 21573060 and 21673068), the Program for Innovative Research Team in Science and Technology in University of Henan Province (No. 16IRTSTHN002), and the Plan for Scientific Innovation Talent of Henan Province (No. 144200510004).

\section{Notes and references}

1 T. Ono, M. Goto, F. Nakashio and T. A. Hatton, Biotechnol. Prog., 1996, 12, 793-800.

2 M. G. Roper, M. L. Frisk, J. P. Oberlander, J. P. Ferrance, B. J. McGrory and J. P. Landers, Anal. Chim. Acta, 2006, 569, 195-202.

3 R. A. Sheldon, R. M. Lau, M. J. Sorgedrager, F. van Rantwijk and K. R. Seddon, Green Chem., 2002, 4, 147-151.

4 J. L. Kaar, A. M. Jesionowski, J. A. Berberich, R. Moulton and A. J. Russell, J. Am. Chem. Soc., 2003, 125, 4125-4131.

5 F. van Rantwijk and R. A. Sheldon, Chem. Rev., 2007, 107, 2757-2785.

6 R. Mareria Lau, F. van Rantwijik, K. R. Seddon and R. A. Sheldon, Org. Lett., 2000, 2, 4189-4191.

7 U. Kragl, M. Eckstein and N. Kaftzik, Curr. Opin. Biotechnol., 2002, 13, 565-571.

8 S. N. Baker, T. M. McCleskey, S. Pandey and G. A. Baker, Chem. Commun., 2004, 40, 940-941.

9 P. Attri, P. Venkatesu and A. Kumar, Phys. Chem. Chem. Phys, 2011, 13, 2788-2796.

10 R. K. Desai, M. Streefland, R. H. Wijffels and M. H. M. Eppink, Green Chem., 2014, 16, 2670-2679.

11 S. Shahriari, C. M. Neves, M. G. Freire and J. A. Coutinho, J. Phys. Chem. B, 2012, 116, 7252-7258.

12 Z. Li, X. Liu, Y. Pei, J. Wang and M. He, Green Chem., 2012, 14, 2941-2950.

13 M. L. Dietz, Sep. Sci. Technol., 2006, 41, 2047-2063.

14 Y. Liu, J. Chen and D. Li, Sep. Sci. Technol., 2012, 47, 223-232.

15 H. Zhao, S. Xia and P. Ma, J. Chem. Technol. Biotechnol., 2005, 80, 1089-1096.

16 D. Cheng, X. Chen, Y. Shu and J. Wang, Talanta, 2008, 75, 1270-1278.

17 K. Shimojo, K. Nakashima, N. Kamiya and M. Goto, Biomacromolecules, 2006, 7, 2-5.

18 K. Fujita, M. Forsyth, D. R. MacFarlane, R. W. Reid and G. D. EIliott, Biotechnol. Bioeng., 2006, 94, 1209-1213. 
19 N. Byrne, L. M. Wang, J. P. Belieres and C. A. Angell, Chem. Commun., 2007, 43, 2714-2716.

20 K. Fujita, N. Nakamura, K. Igarashi, M. Samejima and H. Ohno, Green Chem., 2009, 11, 351-354.

21 X. Lin, Y. Wang, Q. Zeng, X. Ding and J. Chen, Analyst, 2013, 138, 6445-6453.

22 M. G. Freire, A. F. M. Cláudio, J. M. M. Araújo, J. A. P. Coutinho, I. M. Marrucho, J. N. C. Lopes and L. P. N. Rebelo, Chem. Soc. Rev., 2012, 41, 4966-4995.

23 Y. Pei, J. Wang, K. Wu, X. Xuan and X. Lu, Sep. Purif. Technol., 2009, 64, 288-295.

24 H. Yoshimitsu, A. Kanazawa, S. Kanaoka and S. Aoshima, Macromolecules, 2012, 45, 9427-9434.

25 Y. Men, H. Schlaad and J. Yuan, ACS Macro Lett., 2013, 2, 456-459.

26 K. Fukumoto and H. Ohno, Angew. Chem., Int. Ed., 2007, 46, 1852-1855.

27 P. Nockemann, B. Thijs, S. Pittois, J. Thoen, C. Glorieux, K. Van Hecke, L. Van Meervelt, B. Kirchner and K. Binnemans, J. Phys. Chem. B, 2006, 110, 20978-20992.

28 D. Depuydt, L. Liu, C. Glorieux, W. Dehaena and K. Binnemans, Chem. Commun., 2015, 51, 14183-14186.

29 T. V. Hoogerstraete, B. Onghena and K. Binnemans, J. Phys. Chem. Lett., 2013, 4, 1659-1663.

30 M. Blesic, H. Q. N. Gunaratne, J. Jacquemin, P. Nockemann, S. Olejarz, K. R. Seddon and C. R. Strauss, Green Chem., 2014, 16, 4115-4121.

31 Y. Kohno, S. Saita, K. Murata, N. Nakamura and H. Ohno, Polym. Chem., 2011, 2, 862-867.

32 J. Chen, S. K. Spear, J. G. Huddleston and R. D. Rogers, Green Chem., 2005, 7, 64-82.

33 M. M. Cecchini, C. Charnay, F. D. Angelis, F. Lamaty, J. Martinez and E. Colacino, ChemSusChem, 2014, 7, 45-65.

34 S. Tang, G. A. Baker, S. Ravula, J. E. Jonesc and H. Zhao, Green Chem., 2012, 14, 2922-2932.
35 S. Wallert, K. Drauz, I. Grayson, H. Grçger, P. Dominguez de Maria and C. Bolm, Green Chem., 2005, 7, 602-605.

36 H. S. Schrekker, M. A. Gelesky, M. P. Stracke, C. M. L. Schrekker, G. Machado, S. R. Teixeira, J. C. Rubim and J. Dupont, J. Colloid Interface Sci., 2007, 316, 189-195.

37 W. Yao, H. Wang, G. Cui, Z. Li, A. Zhu, S. Zhang and J. Wang, Angew. Chem., Int. Ed., 2016, 55, 7934-7938.

38 W. Yao, H. Wang, G. Cui, Z. Li and J. Wang, Phys. Chem. Chem. Phys., 2016, 18, 29192-29198.

39 M. G. Freire, P. J. Carvalho, R. L. Gardas, I. M. Marrucho, L. M. Santos and J. A. Coutinho, J. Phys. Chem. B, 2008, 112, 1604-1610.

40 R. A. Scott and A. G. Mauk, Cytochrome c: a multidisciplinary approach. University Science Books, 1996.

41 J. R. Telford, P. W. Stafshede, H. B. Gray and J. R. Winkler, Acc. Chem. Res., 1998, 31, 755-763.

42 N. V. Kawahara and H. Ohno, Solid State Ionics, 1998, 113, 161-166.

43 S. Li, J. L. Bañuelos, P. Zhang, G. Feng, S. Dai, G. Rotherc and P. T. Cummings, Soft Matter, 2014, 10, 9193-9200.

44 T. Ishida and H. Shirota, J. Phys. Chem. B, 2013, 117, 11361150.

45 J. D. Holbrey, A. E. Visser, S. K. Spear, W. M. Reichert, R. P. Swatloski, G. A. Broker and R. D. Rogers, Green Chem., 2003, 5, 129-135.

46 M. Bihari, T. P. Russell and D. A. Hoagland, Biomacromolecules, 2010, 11, 2944-2948.

47 K. Shimojo, N. Kamiya, F. Tani, H. Naganawa, Y. Naruta and M. Goto, Anal. Chem., 2006, 78, 7735-7742.

48 J. W. Brauner, C. R. Flach and R. Mendelsohn, J. Am. Chem. Soc., 2005, 127, 100-109.

49 S. Strassburg, H. Bermudez and D. Hoagland, Biomacromolecules, 2016, 17, 2233-2239.

50 K. Fujita, D. R. MacFarlane and M. Forsyth, Chem. Commun., 2005, 41, 4804-4806. 